\title{
Hybrid Energy Sources for Electric and Fuel Cell Vehicle Propulsion
}

\author{
N. Schofield (MIEE) $)^{1 \#}$, H. T. Yap (MIEE) ${ }^{1}$ and C. M. Bingham (MIEEE) ${ }^{2}$ \\ ${ }^{1 \#}$ School of Electrical and Electronic Engineering, University of Manchester, M60 1QD, UK. \\ ${ }^{2}$ Department of Electronic and Electrical Engineering, University of Sheffield, S1 3JD, UK \\ \# Corresponding author: nigel.schofield@manchester.ac.uk
}

\begin{abstract}
Given the energy (and hence range) and performance limitations of electro-chemical batteries, hybrid systems combining energy and power dense storage technologies have been proposed for electric vehicle propulsion. The paper will discuss the application of electro-chemical batteries, supercapacitors and fuel cells in single and hybrid source configurations for electric vehicle drive-train applications. Simulation models of energy sources are presented and used to investigate the design optimisation of electric vehicle on-board energy source in terms of energy efficiency and storage mass/volume.

Results from a case study considering a typical small urban electric vehicle are presented, illustrating the benefits of hybrid energy sources in terms of system mass and vehicle range. The models and approach can be applied to other vehicles and driving regimes.
\end{abstract}

Index terms - Electric vehicles, electro-chemical batteries, supercapacitors, hydrogen fuel cells, hybrid energy source energy source models.

\section{INTRODUCTION}

$\mathrm{E}$ lectric vehicles are set to play a prominent role in addressing the energy and environmental impact of an increasing road transport population by offering a more energy efficient and less polluting drive-train alternative to conventional internal combustion engine (ICE) vehicles. Whilst there are many technical and resource management issues associated with the displacement of petroleum fuels for transportation, and the commensurate fuel supply infrastructure, this paper will discuss the application of electro-chemical batteries, supercapacitors and fuel cells in single and hybrid energy sources for electric vehicle traction systems.

For road vehicle applications, the on-board energy and power sources must satisfy the load demand of the vehicle traction drive-train. The decision as to whether the on-board energy source supplies all of the vehicle load or simply the average energy requirements, via a hybrid configuration utilising a power buffer, can significantly influence the sizing of the vehicle energy/power storage system and hence total drive system cost. The difficulty in making this assessment is in choosing the most appropriate duty rating specification for the vehicle $[1,2]$. For example, Fig. 1(a) illustrates the Fiat Electtra, a typical small 1.5 tonne urban electric vehicle that will be used as the reference vehicle throughout the paper. Fig. 1(b) illustrates the NEDC vehicle driving cycle comprising of four European Commission R15.04 urban (ECE15) and one EC sub-urban velocity profile, whilst Fig. 1(c) illustrates the dynamic power required to propel the Fiat Electtra over the NEDC driving cycle. The vehicle average (energy) and peak power over the NEDC cycle are tabulated in Table I together with results for the same vehicle when considering the highway fuel economy test schedule (HWFET), US 1975 driving schedule (FTP75) and Japanese 11-mode test schedule (J11). Two operating scenarios are considered, one with, and one without the recovery of regenerative braking energy. Note, that whilst all sources are a source of energy to some greater or lesser degree, reference is made here to energy and power to emphasise the functionality of the vehicle sources with respect to the vehicle energy management philosophy, the objective of which, for hybrid source configurations, is to realise optimum utilisation of the on-board energy and power dense sources.

From Table I, it can be seen that there is a wide disparity between vehicle average and peak power requirements, which is typical for urban driving. Hence, specifying the on-board energy source to satisfy the instantaneous vehicle electrical load can lead to significant over-sizing with the resulting implications on system volume, mass and cost. There are, therefore, clear benefits in terms of mass minimisation, energy efficiency and the recovery of vehicle regenerative braking energy, for the operation of hybrid energy system configurations, an example of which is illustrated by the generalised vehicle drive-train schematic of Fig. 2 , showing various options for energy storage devices, peak power buffers and their associated interconnection, for a series electrical drive-train implementation. Here, the energy source may provide the traction drive DClink with the peak power buffer interfaced via a DC:DC converter (Option I), or alternatively, the peak power buffer may provide the DC-link with the energy source interfaced via a DC:DC converter (Option II).

The exploitation of the disparity in vehicle peak and average power requirement is at the core of hybridelectric vehicle operational philosophy, particularly where the energy source is an ICE and the goal is to 
reduce engine size and hence improve on emissions and fuel economy. A number of authors [3-6] have showed that by choosing a single energy source, the source tends to be oversized. Additionally, for single source systems, there are limitations on vehicle dynamic performance in terms of responsive braking and the recovery of vehicle regenerative energy. This paper confirms these findings and investigates the optimisation of hybrid sources by considering two case studies for the reference vehicle of Fig. 1, viz.:

- an electro-chemical battery (lead-acid) and supercapacitor combination, and

- a hydrogen PEM fuel cell and supercapacitor combination.
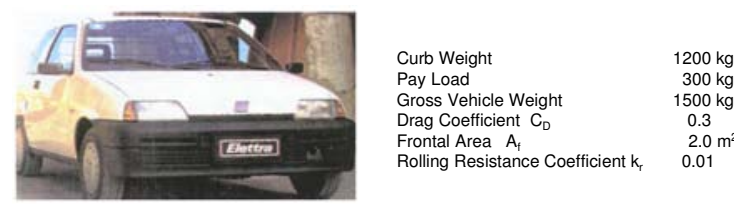

(a) Urban electric vehicle the FIAT Electtra

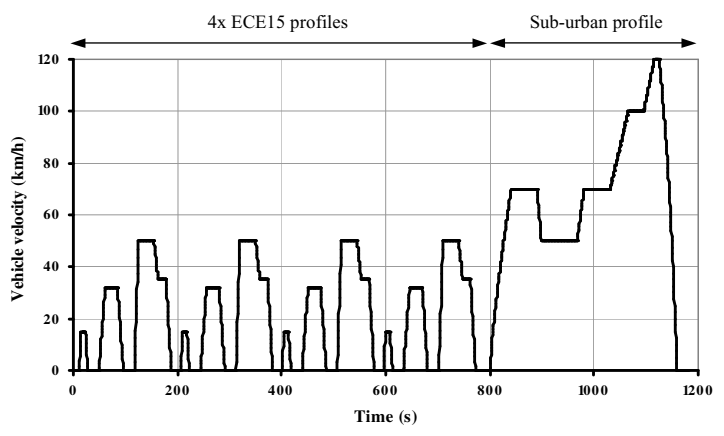

(b) Vehicle reference driving cycle the NEDC

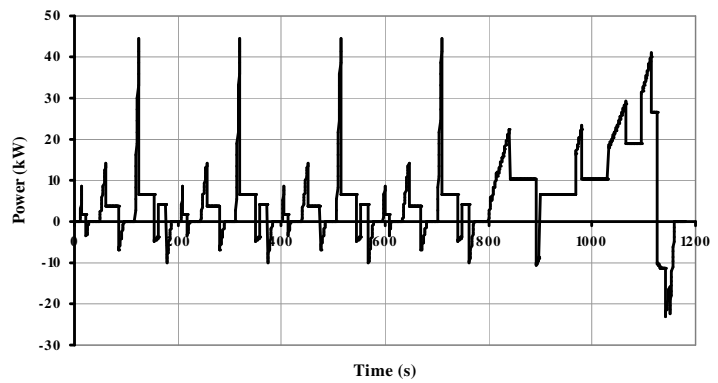

(c) Vehicle power requirements

Fig. 1. Urban electric vehicle data and typical power requirements for urban and sub-urban driving.

As a benchmark, the default on-board energy system for the reference electric vehicle is based on 18 Hawker, Genesis EP Series, 70Ah-12V lead-acid (Pb-acid) batteries scaled to $80.7 \mathrm{Ah}-12 \mathrm{~V}$, and 128 Maxwell PC2500 supercapacitors. The total mass and volume for the benchmark energy system is $602.5 \mathrm{~kg}$ and 277.41 itres respectively. The mass and volumes include housings, connections, cell and thermal management systems. Although the calculated mass data will be indicative of an actual vehicle system, the component volumes are based on existing prototype bench-test systems and are, as a consequence, non-optimal. For future vehicle applications the design of vehicle specific, non-regular shape components, could lead to improved volumetric packaging. Hence, for this study, the total maximum energy source mass is fixed while two scenarios are considered for volume, one being related to maximum mass and the other to the benchmark system volume, the assumption being that any future energy source would lie between these two design extremes. The energy source interconnection was chosen as Option I of Fig.2, where it is assumed that the power buffer energy management realises a $90 \%$ utilisation of the of power buffer (i.e. supercapacitor) energy spectrum. The system DC:DC converter is modelled with a high efficiency $(>90 \%)$ details of which may be found in [7].

Table I. Summary of power requirements for various acknowledged vehicle driving profiles.

\begin{tabular}{|c|c|c|c|c|}
\hline $\begin{array}{c}\text { Driving } \\
\text { cycle } \\
\text { profile }\end{array}$ & $\begin{array}{l}\text { Re-gen. } \\
\text { braking }\end{array}$ & $\begin{array}{c}\text { Cycle } \\
\text { Time } \\
\text { (s) }\end{array}$ & $\begin{array}{l}\text { Average } \\
\text { power } \\
(\mathrm{kW})\end{array}$ & $\begin{array}{c}\text { Peak } \\
\text { power } \\
(\mathrm{kW}\end{array}$ \\
\hline \multirow{2}{*}{ NEDC } & Yes & \multirow{2}{*}{1180} & 5.3 & \multirow{2}{*}{44.5} \\
\hline & No & & 6.5 & \\
\hline \multirow{2}{*}{$\begin{array}{l}\text { Enhanced } \\
\text { ECE15 }\end{array}$} & Yes & \multirow{2}{*}{195} & 2.7 & \multirow{2}{*}{44.5} \\
\hline & No & & 3.4 & \\
\hline \multirow{2}{*}{$\begin{array}{c}\text { NEDC } \\
\text { Sub-urban }\end{array}$} & Yes & \multirow{2}{*}{400} & 10.2 & \multirow{2}{*}{40.6} \\
\hline & No & & 11.5 & \\
\hline \multirow{2}{*}{ HWFET } & Yes & \multirow{2}{*}{765} & 12.6 & \multirow{2}{*}{32.2} \\
\hline & No & & 13.2 & \\
\hline \multirow{2}{*}{ FTP75 } & Yes & \multirow{2}{*}{1372} & 4.5 & \multirow{2}{*}{38.7} \\
\hline & No & & 5.7 & \\
\hline \multirow{2}{*}{ J11 } & Yes & \multirow{2}{*}{120} & 4.1 & \multirow{2}{*}{21.8} \\
\hline & No & & 5.4 & \\
\hline
\end{tabular}

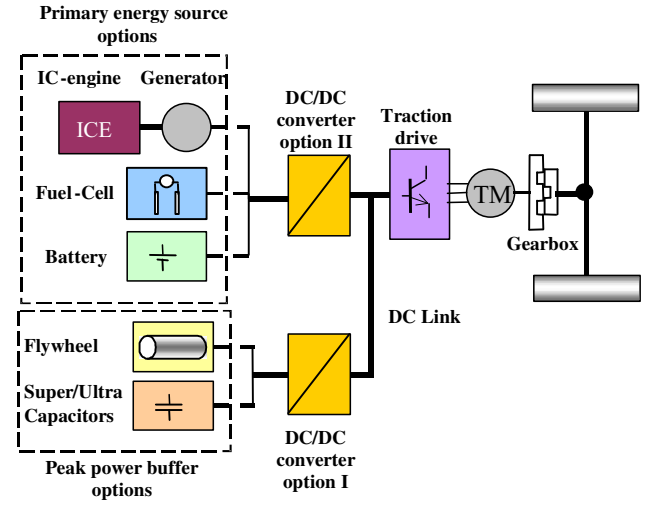

Fig. 2. Options for electric vehicle traction system energy and power sources and their combination.

\section{LEAD-ACID BATTERIES AND SUPERCAPACITORS}

\section{A. Simulation models}

A major operational problem associated with most electro-chemical traction batteries, and lead-acid batteries in particular, is their degradation in performance at high current discharge/charge rates, 
typical of vehicle acceleration and braking demands $[8,9]$. For example, repetitive high power demands, even for a short duration (2-3s), can limit battery energy utilisation due to battery voltage regulation, as will be shown later. More importantly, high cyclic operation reduces battery life adding a significant premium to the operating costs of an electric vehicle. The incorporation of a peak power buffer into an electric vehicle drivetrain can reduce the peak power load on the primary energy source, resulting in a significant improvement in battery energy utilisation due to levelling of the battery energy demand. Additionally, the response of the vehicle is more consistent when accelerating and braking, and the recovery of vehicle kinetic energy during braking enhanced, since the drive-train energy management is independent of the traction battery stateof-charge (SOC) or terminal voltage.

Simulation of the battery and battery-supercapacitor combination is facilitated via a detailed analytic model of the two technologies validated via test data taken from a vehicle drive-train platform [1]. The battery model implements a detailed non-linear characteristic of both discharge and charging resistance to model performance during these regimes. The characteristics are based in experimental results taken during the characterisation of Hawker Genesis $70 \mathrm{Ah}-12 \mathrm{~V}$ sealed lead-acid batteries. The SC system comprises of 128 series connected, 2500F, 2.5V nominal, Maxwell PC2500 SCs, which are modelled as a simple R-C circuit, $\mathrm{R}$ being the device leakage resistance and $\mathrm{C}$ the capacitance, as taken from manufacturer $\mathrm{s}$ data sheets [10] and validated by bench test.

Since the battery loadings are relatively low frequency $(<100 \mathrm{~Hz}$ for the NEDC), the battery equivalent circuit model can be simplified to that illustrated in Fig. 3(a). The open-circuit terminal voltage of the battery depends on battery SOC, and is found from test to be independent of load current, Fig. 3(b). SOC is defined as a ratio of charge left in the battery, with respect to a specified maximum charge capacity taken from the manufacturer s nameplate capacity and collaborated via a series of Peukert tests. Both the discharging and charging internal resistances are determined from test and are a function of the battery SOC and discharging/charging current rate, Fig. 3(c) and 3(d) respectively. The main specification details of the Hawker Pb-acid battery and Maxwell supercapacitor are given in Appendix I. Note, that the Pb-acid battery model is based on an ambient cooling temperature of $20 \mathrm{C}$, which is not unrealistic since, in practice, a cooling system would be required for $\mathrm{Pb}$-acid batteries to maximise battery energy utilisation. Hence, the effect of higher battery operating temperature would need further consideration.

\section{B. Pure battery EV operation}

To illustrate the impact of vehicle load demand on battery performance, the reference vehicle of Fig. 1(a) is considered driving over repetitive ECE15 and NEDC velocity profiles. The upper and lower voltage limits of each of the lead-acid batteries were set to $16.0 \mathrm{~V}$ and $10.2 \mathrm{~V}$ respectively. Fig. 4 illustrates an example of simulated and experimental results of battery terminal voltage variation, showing good correlation and demonstrating the utility of the battery model over dynamic load profiles commensurate with vehicle operation.

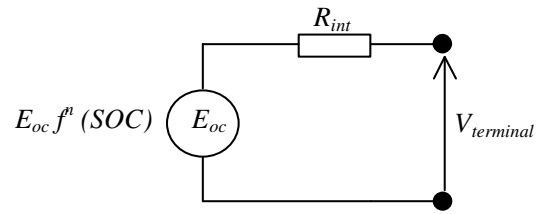

(a) Equivalent circuit model for lead-acid battery

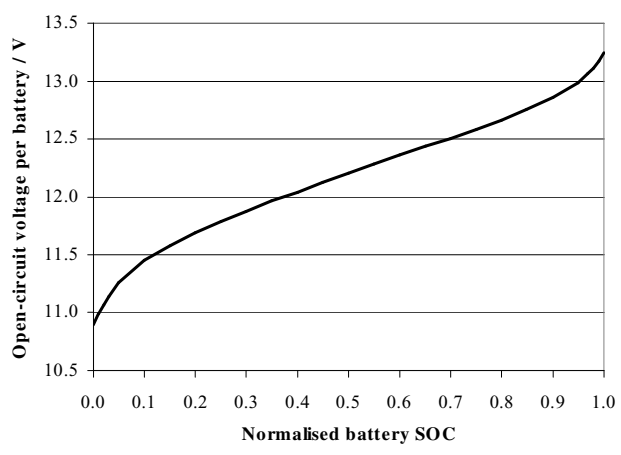

(b) Open circuit terminal voltage

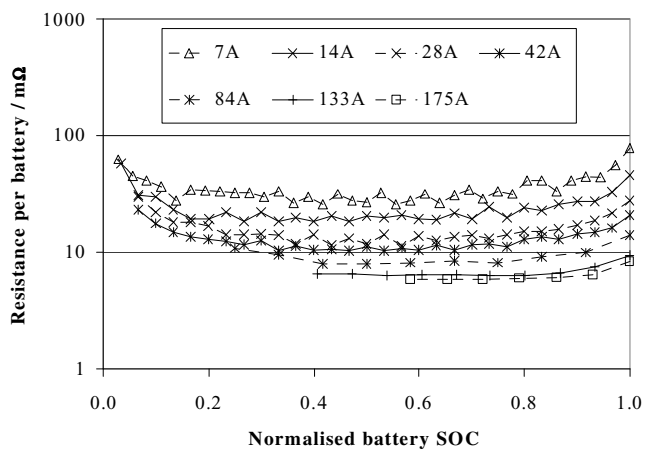

(c) Discharging internal resistance

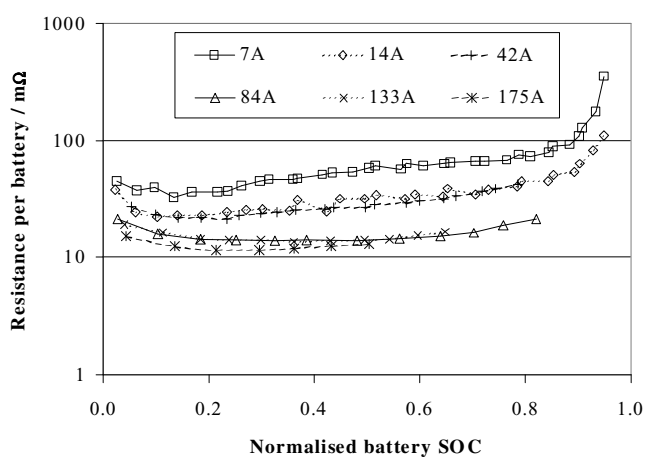

(d) Charging internal resistance

Fig. 3. Lead-acid battery equivalent circuit model. 


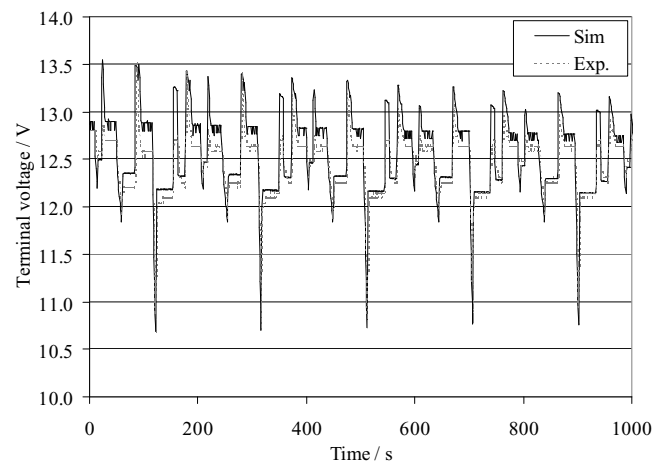

Fig. 4. Simulated and measured battery terminal voltage for pure electric vehicle operation.

Fig. 5 illustrates the battery terminal voltages for both driving cycles from full battery SOC to the point when the minimum set-point voltage of $10.2 \mathrm{~V}$ (per battery) is reached. Note, the upper voltage transients occur during regenerative braking and the lower voltage transients during peak acceleration. These lower voltage transients ultimately limit battery energy utilisation to 0.43 and 0.44 SOC, for Case 1 and 3 respectively, by virtue of the battery management system (which monitors the $16.0 \mathrm{~V}$ and $10.2 \mathrm{~V}$ limits).

For repetitive cycling of the dynamic load profiles considered, the battery is capable of supplying energy equating to a vehicle range of $68.6 \mathrm{~km}$ for the urban ECE15 and $60.5 \mathrm{~km}$ for the NEDC, the reduction due to the additional energy demand of the sub-urban profile of the NEDC.

\section{Battery-supercapacitor hybrid}

The driving regimes considered for the pure electric scenario are now applied to the lead-acid batterysupercapacitor hybrid energy source configuration, and the battery capacity and SC rating are optimised to minimise battery peak current while maximising vehicle range. Calculated performance data is given in Table II for comparison with the pure EV solutions, Cases 1 and 3. Referring to Case 1 and 2 of Table II, it can be observed that there is an improvement in range for urban driving due to the better utilisation of the on-board battery energy source, from 0.43 to 0.17 SOC due, primarily, to a reduction of battery peak current (242 to $55 \mathrm{~A})$ and hence a reduction in transient voltage drop at the battery terminals facilitated by the vehicle energy management that tries to maintain a low battery current by utilising the SC power buffer during drive-train transients.

For the NEDC cycle there is no improvement in range for the hybrid energy source, Case 4 , since the sub-urban element of the driving cycle is energy demanding. However, utilising the battery and SC specifications optimised for the ECE15 cycle, Case 2, does lead to a reduction in peak battery current an important feature for battery life, and also in Ah specification, Case 4. Optimising the energy sources for the NEDC cycle yields a slightly smaller battery capacity and SC than for the urban case. This combination yields a reduced peak battery current and a range improvement of $12 \%$

Hence, the inclusion of a peak power buffer enables the electric vehicle primary energy source to be operated for a longer period before the battery terminal voltage reaches the minimum limit imposed by the battery management system. The reduced transient battery current improves battery lifetime, although this is not evaluated here. Furthermore, the hybrid configuration has the potential of improving overall energy efficiency since the SC has a much higher discharge/charge efficiency when compared to a lead-acid battery [11].

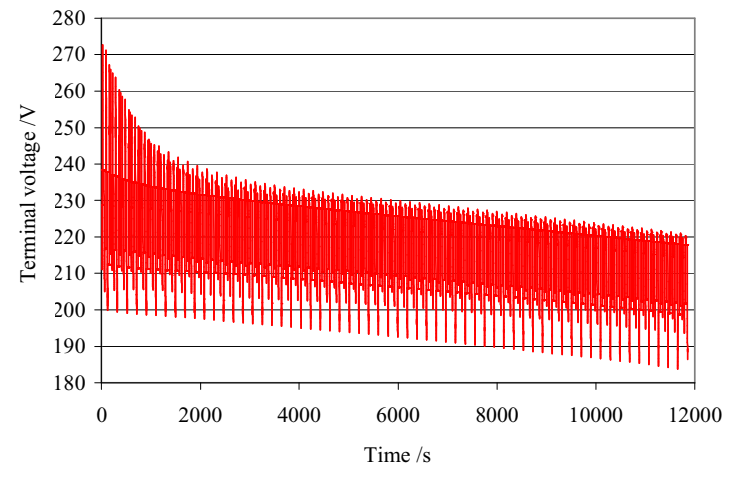

(a) ECE15; Case 1, battery alone

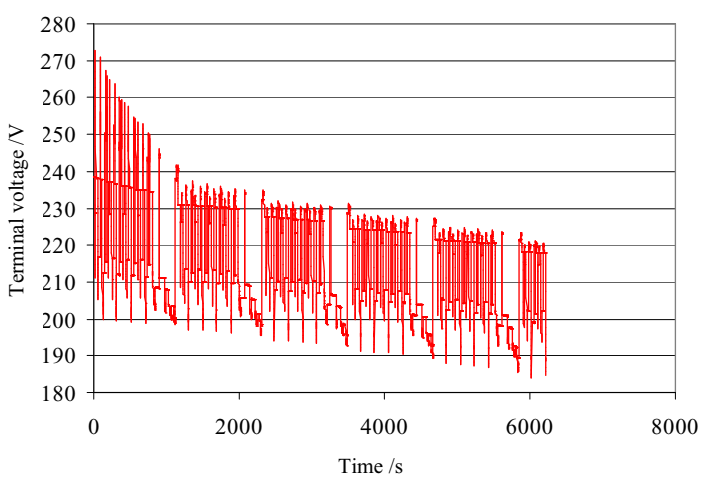

(b) NEDC, Case 3, battery alone

Fig. 5. Terminal voltage for pure battery EV operation.

Table II. Pure Pb-acid battery and battery-SC hybrid energy source operation

\begin{tabular}{|c|c|c|c|c|c|c|}
\hline & \multicolumn{3}{|c|}{ Battery } & SC & \multicolumn{2}{c|}{ Totals } \\
\hline $\begin{array}{c}\text { 黑 } \\
\text { Capacity } \\
(\text { Ah) }\end{array}$ & $\begin{array}{c}\text { Peak current } \\
(\mathrm{A})\end{array}$ & $\begin{array}{c}\text { End } \\
\text { SOC }\end{array}$ & $\begin{array}{c}\text { Energy } \\
(\mathrm{kJ})\end{array}$ & $\begin{array}{c}\text { Volume } \\
(\mathrm{l})\end{array}$ & $\begin{array}{c}\text { Range } \\
(\mathrm{km})\end{array}$ \\
\hline \multicolumn{7}{|c|}{ ECE15 } \\
\hline 1 & 80.7 & 242 & 0.43 & 0 & 243.7 & 68.6 \\
\hline 2 & 70.0 & 55 & 0.17 & 781.3 & 277.4 & 84.5 \\
\hline NEDC & 80.7 & 242 & 0.44 & 0 & 243.7 & 60.5 \\
\hline 3 & 70.0 & 150 & 0.33 & 781.3 & 277.4 & 60.5 \\
\hline 4 & 70.3 & 0.32 & 102.8 & 248.1 & 68.2 \\
\hline 5 & 79.3 & 165 &
\end{tabular}

Note: Total energy source mass $=602.5 \mathrm{~kg}$ for all cases 


\section{FuEl CELl AND SUPERCAPACITOR SySTEMS}

\section{A. Background}

A major advantage of fuel cell powered vehicles is the development of cleaner, more energy efficient cars, trucks, and buses that can initially operate on conventional fuels, i.e. gasoline and diesel, whilst enabling drive-train technologies for a future move to renewable and alternative fuels, i.e. methanol, ethanol, natural gas, and other hydro-carbons, and ultimately hydrogen, a particularly significant issue when considering the infrastructure and support requirements of a modern transportation network. With on-board fuels other than pure hydrogen, for example, natural gas, methanol and gasoline, the fuel cell systems could use an appropriate fuel processor to convert the fuel to hydrogen. Since the fuel cell relies on chemistry and not combustion, emissions from this type of a system should, potentially, be much smaller than emissions from the cleanest fuel combustion process emissions, whilst offering the advantages of an electric transmission. However, disadvantages of fuel cells in traction systems is their voltage regulation and inability to accept vehicle kinetic energy during braking, hence the consideration of a hybrid energy source.

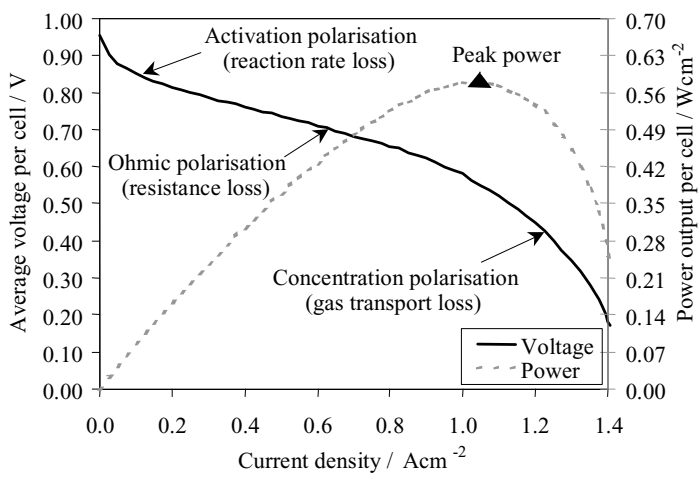

Fig. 6. Measured $\mathrm{H}_{2}$ PEM FC voltage and power density curves.

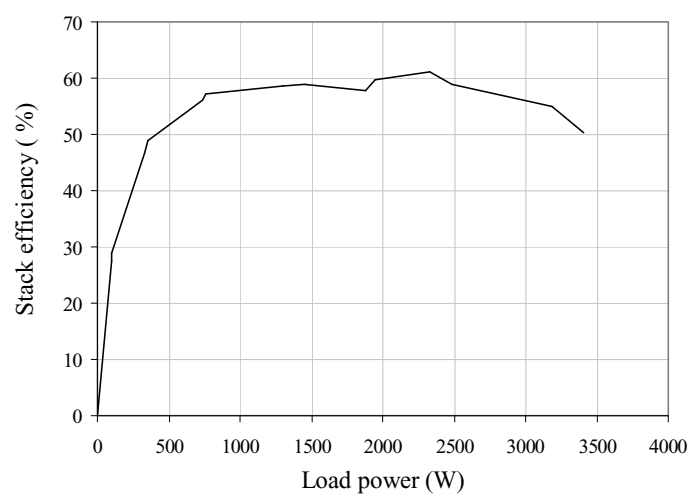

Fig. 7. Measured fuel cell stack hydrogen-to-electrical energy efficiency with output load.

\section{B. Fuel cell model}

As with electro-chemical batteries, fuel cells exhibit non-linear performance characteristics that can significantly influence vehicle drive system operation and component optimisation if not considered at the system design stage. For example, the three main fuel cell (FC) loss mechanisms, activation, concentration and ohmic or resistance polarisation loss, all influence FC performance, as illustrated in Fig. $6[12,13]$, showing measured $\mathrm{H}_{2}$ PEM FC system polarisation and power density curves for load current density [14]. Fig. 7 illustrates the measured fuel cell stack hydrogen-toelectrical energy efficiency with output load. Since the fuel cell considered is operated at a near fixed inlet pressure and the stack temperature closely regulated, the fuel cell characteristics of Figs. 6 and 7 are sufficient to model the fuel cell for on-vehicle simulation. Suitable curve fits to the characteristics are made such that the model can be implemented analytically to reduce computation time.

Table III. FC and SC hybrid energy source specifications

\begin{tabular}{|c|c|c|c|c|c|c|c|c|}
\hline & \multicolumn{2}{|c|}{ Fuel cell } & \multicolumn{2}{|c|}{ Supercapacitor } & \multicolumn{2}{|c|}{ Cylinder } & \multicolumn{2}{|c|}{ Total } \\
\hline 总 & 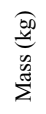 & 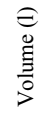 & 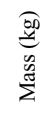 & $\begin{array}{l}\stackrel{\ominus}{\Xi} \\
\stackrel{\Xi}{\Xi} \\
\stackrel{0}{0}\end{array}$ & 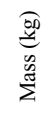 & 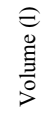 & 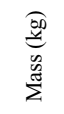 & $\begin{array}{l}\underset{\Xi}{\Xi} \\
\stackrel{\Xi}{\Xi} \\
\stackrel{0}{0}\end{array}$ \\
\hline 1 & 163 & 501 & 0 & 0 & 439 & 1140 & 602.5 & 1640 \\
\hline 2 & 10 & 31 & 32 & 26 & 561 & 1455 & 602.5 & 1512 \\
\hline 3 & 10 & 31 & 32 & 26 & 85 & 220 & 126.8 & 277 \\
\hline 4 & 19 & 59 & 321 & 266 & 262 & 681 & 602.5 & 1005 \\
\hline 5 & 19 & 59 & 321 & 266 & 112 & 290 & 452.0 & 615 \\
\hline
\end{tabular}

Table IV. Simulation results for FC and FC-SC hybrid energy source

\begin{tabular}{|c|c|c|c|c|c|}
\hline \multicolumn{6}{|c|}{ ECE15 } \\
\hline נ్ & $\begin{array}{c}\text { FC Peak } \\
\text { power } \\
(\mathrm{kW})\end{array}$ & $\begin{array}{c}\text { SC } \\
\text { energy } \\
(\mathrm{kJ})\end{array}$ & $\begin{array}{c}\text { Storage } \\
\text { pressure } \\
\text { (bar) }\end{array}$ & $\begin{array}{c}\text { Range } \\
(\mathrm{km})\end{array}$ & $\begin{array}{c}\text { FC } \\
\text { average } \\
\text { efficiency }\end{array}$ \\
\hline \multirow{2}{*}{1} & \multirow{2}{*}{44.5} & \multirow{2}{*}{0} & 230 & 425 & \multirow{2}{*}{0.24} \\
\hline & & & 700 & 1001 & \\
\hline \multirow{2}{*}{2} & \multirow{2}{*}{2.7} & \multirow{2}{*}{313} & 230 & 1375 & \multirow{2}{*}{0.56} \\
\hline & & & 700 & 3236 & \\
\hline \multirow{2}{*}{3} & \multirow{2}{*}{2.7} & \multirow{2}{*}{313} & 230 & 208 & \multirow{2}{*}{0.56} \\
\hline & & & 700 & 490 & \\
\hline \multicolumn{6}{|c|}{ NEDC } \\
\hline ũ & $\begin{array}{c}\text { FC Peak } \\
\text { power } \\
(\mathrm{kW})\end{array}$ & $\begin{array}{c}\mathrm{SC} \\
\text { energy } \\
(\mathrm{kJ})\end{array}$ & $\begin{array}{c}\text { Storage } \\
\text { pressure } \\
\text { (bar) }\end{array}$ & $\begin{array}{c}\text { Range } \\
(\mathrm{km})\end{array}$ & $\begin{array}{c}\text { FC } \\
\text { average } \\
\text { efficiency }\end{array}$ \\
\hline \multirow{2}{*}{1} & \multirow{2}{*}{44.5} & \multirow{2}{*}{0} & 230 & 538 & \multirow{2}{*}{0.31} \\
\hline & & & 700 & 1263 & \\
\hline \multirow{2}{*}{4} & \multirow{2}{*}{5.3} & \multirow{2}{*}{3143} & 230 & 561 & \multirow{2}{*}{0.56} \\
\hline & & & 700 & 1318 & \\
\hline 5 & 5.3 & 3143 & 700 & 561 & 0.56 \\
\hline
\end{tabular}


The fuel cell and storage specifications are given in Appendix I and the fuel cell model equations and equation parameters in Appendix II for reference.

\section{System studies.}

For a vehicle supplied solely via fuel cells, operation at low cell current densities would be required to minimise the voltage regulation of the dc supply to the vehicle traction system, Fig. 6. To address the FC voltage regulation and regenerative limitations, a FC-SC hybrid energy source is considered, with the respective component specifications evaluated over repetitive ECE15 and NEDC driving cycles. Note, the timetransient response of the FC fuelling has to be considered at the design stage, a feature that also fosters operation in a hybrid energy source configuration.

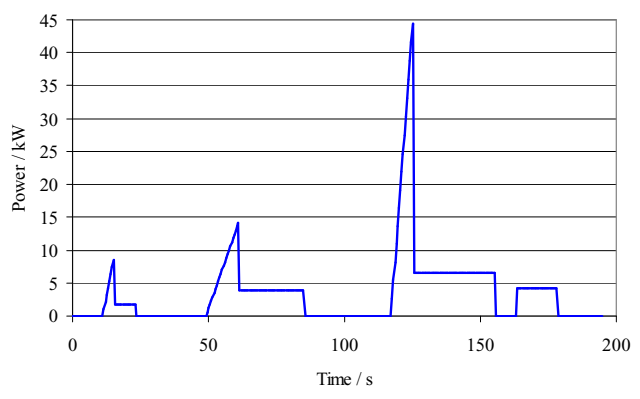

(a) FC output power vs. time

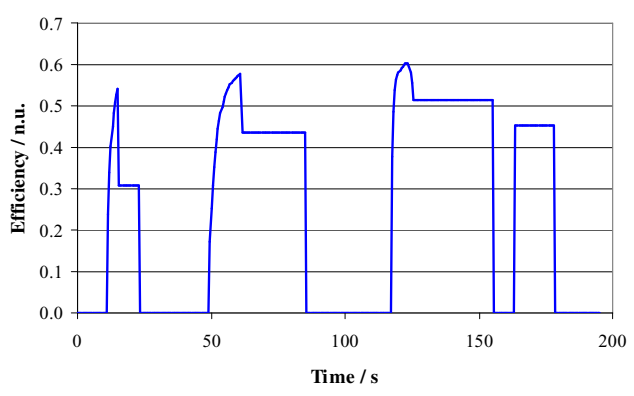

(b) FC efficiency vs. time

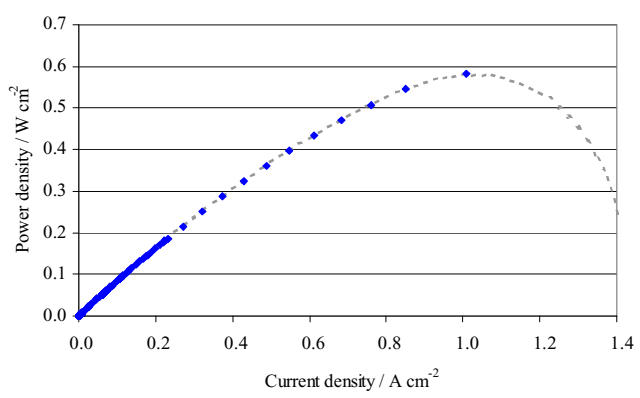

(c) FC output power vs. current density

For the study, the battery benchmark reference is used as the default energy system mass and volume, with connection Option I of Fig. 2 chosen to maximise the SC energy. Also, two different storage cylinder pressures are considered, i.e. $230 \mathrm{bar}$ and $700 \mathrm{bar}$, based on current state-of-art and projected future storage pressures respectively [15]. An assumption is made that the mass and volume for the 700bar storage is as for the 230bar system. However, it must be noted that hydrogen gas is not an ideal gas; the energy content at 700bar is not linearly proportional to $230 \mathrm{bar}$. For the same volume, the 700 bar cylinder contains only $2.35 \mathrm{x}$ the hydrogen energy of a 230bar cylinder [15].

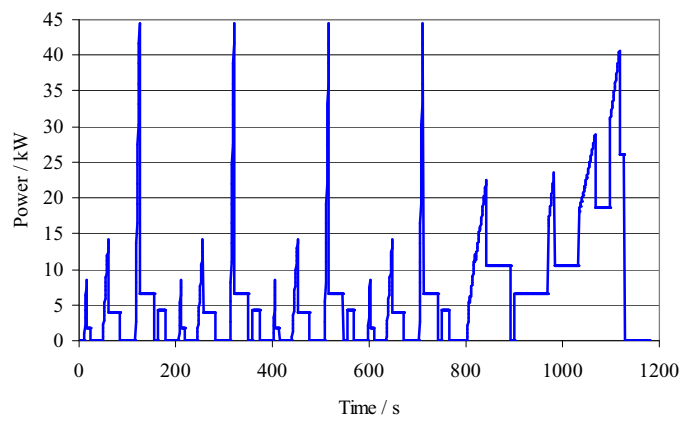

(a) FC output power vs. time

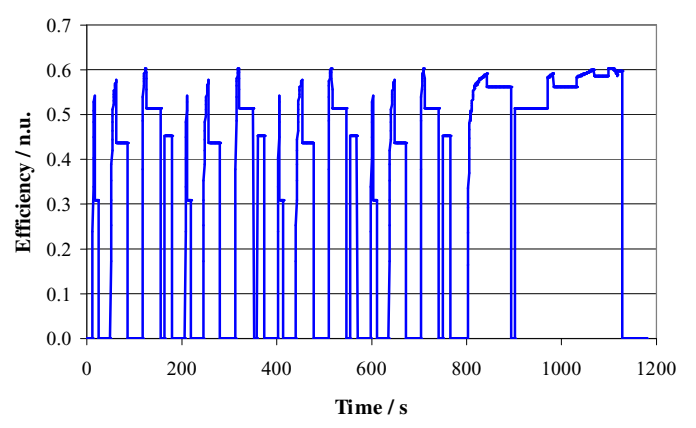

(b) FC efficiency vs. time

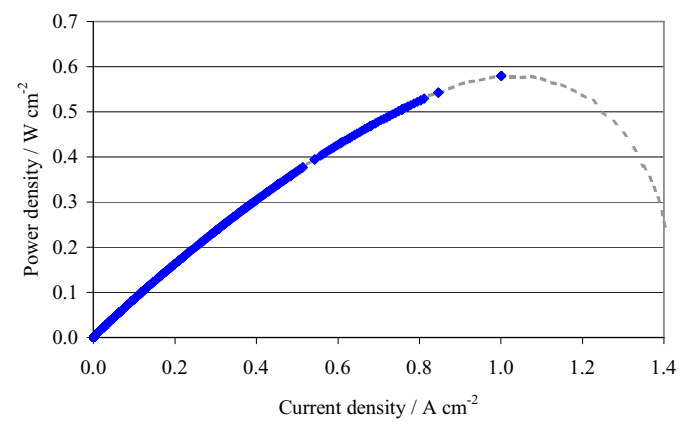

(c) FC output power vs. current density

Fig. 9. $44.5 \mathrm{~kW}$ FC system simulation results over NEDC.

For a pure fuel cell powered vehicle an installed fuel cell output power capability of $44.5 \mathrm{~kW}$ is required. It can be seen that the fuel cell volume alone already exceeds the volume of the battery benchmark energy source, exclusive of any gas storage cylinders, Case 1 of 
Table III. Hence, it will be assumed that the energy source volumetric requirement will be satisfied by future component integration and volume design optimisation. Consequently, range is calculated for the ECE15 and NEDC cycles, Cases 1 of Table IV, for both hydrogen storage pressures. Fig. 8 illustrates simulation results for a pure fuel cell vehicle on the ECE15 driving cycle, showing the simulated fuel cell output power (a), hydrogen-to-electrical efficiency (b) and fuel cell power output vs. stack current density (c) - highlighting the poor utilisation of the fuel cell stack. Similarly, Fig. 9 illustrates results for the pure fuel cell vehicle over the NEDC cycle. The quoted figures fuel cell average efficiency of Table IV are the average hydrogen-toelectrical efficiency over the respective driving cycle.

If the fuel cell rating is chosen to provide the drivesystem average energy, the fuel cell mass can be reduced considerably as shown in Table III, Cases 2 to 5 . However, the required supercapacitor peak power buffer increases the overall energy source mass and volume. As a direct comparison to the pure fuel cell vehicle, a FC-supercapacitor hybrid energy source can significantly improve vehicle range for urban driving, by a factor of 3.2 for the ECE15, Case 2. However, as with the battery-SC hybrid, range is only marginally improved for the NEDC cycle, Case 4, although for a much reduced energy source volume as a consequence of the higher achievable average energy efficiency and the recovery of regenerative energy. If the calculated range of $561 \mathrm{~km}$ for Case 4 is acceptable, Case 5 investigates the achievable reduction in cylinder mass and volume for the high pressure storage scenario.

An interesting case arises for the ECE15 cycle due to the high peak-to-average duty rating. This disparity can be exploited allowing a reduced hydrogen storage volume and hence reduced total energy source volume, to an extent that equates to the battery vehicle benchmark specification, Case 3 of Tables III and IV. Here, the energy source mass is also reduced to $21 \%$ that of the benchmark vehicle, whilst vehicle range is increased by 2.4 or 5.8 times that of the battery vehicle depending upon storage pressure. Fig. 10 illustrates the fixed operating point philosophy for the $2.7 \mathrm{~kW}$ FC-SC hybrid energy source of Cases 2 and 3.

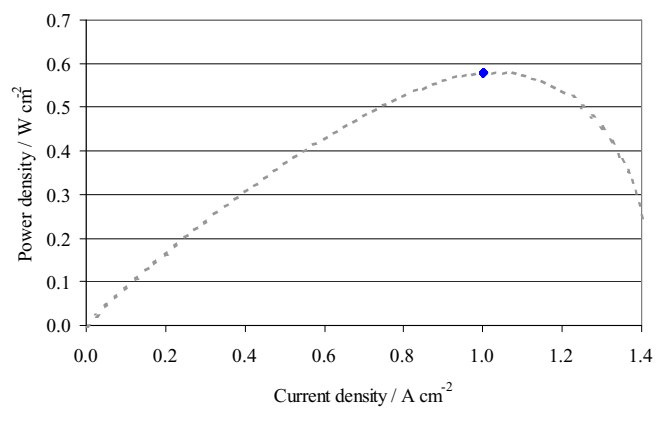

Fig. 10. 2.7kW FC; $313 \mathrm{~kJ}$ SC hybrid energy source FC output power vs. current density

\section{CONCLUSIONS}

The paper has investigated the application of electrochemical batteries, supercapacitors and fuel cells in single and hybrid source configurations for electric vehicle drive-train applications. Simulation models of energy sources have been presented and used to investigate the design optimisation of electric vehicle on-board energy source in terms of energy efficiency and storage mass/volume in the form of case studies considering a typical small urban electric vehicle. The models and approach can be applied to other vehicles and driving regimes.

The study results illustrate the benefits of hybrid energy sources in terms of energy source mass, vehicle range and system functionality i.e. (i) the recovery or regenerative energy, (ii) the reduction of battery current loading (iii) the improvement of fuel cell energy conversion efficiency and (iv) the separation of drivetrain transients from the main energy source to the system power buffer.

The results highlight the limitations of battery vehicles in terms or range, though the battery-SC energy source would be ideal for urban specific driving, for example city delivery / postal applications. The fuel cell hybrid concept looks promising in terms or vehicle range being comparable with existing combustion engine vehicles. Although the volumetric challenges of integrated energy sources need to be addressed by future vehicle system designers.

Non of the preceding discussion has considered cost, which is ultimately the dominant consideration from an automotive prospective, since both fuel cells and supercapacitors are at an early stage of technical development and cost projections for high volume application vary considerably. However, the optimisation procedure employed can be extended to include cost functions, although this is outside the scope of this paper.

\section{ACKNOWLEDGMENTS}

The authors acknowledge the support of the UK Engineering and Physical Science Research Council (EPSRC), via Grant No. GR/S81971/01; SEMELAB PLC, UK, for provision of a research studentship and Beta R\&D, Derby, UK, for provision of test data and technical information.

\section{REFERENCES}

[1] Energy optimised traction system for electric vehicle (OPTELEC) , Project funded by the EC under Framework IV, Project No. BE97-4502.

[2] N. Schofield, C. M. Bingham, and D. Howe. Regenerative braking for all-electric vehicles, IMechE Conf. Braking 2002, pp.175-183, 2002.

[3] N. Schofield, H. T. Yap, G. Maggetto, P. Van den Bossche, and J. Van Mierlo, A state-of-the-art review and database of fuel cells and their application in electric vehicles useful for education needs , Proc. 10th European Conf. on Power Electronics and Applications (EPE2003), CD ROM, Paper 906, pp.1-10, 2003. 
[4] O. Briat, J. M. Vinassa, W. Lajnef, S. Azzopardi, and C. Zardini, Experimental comparison of two hybridisation strategies for ESS-battery association in heavy duty electric vehicles, Proc. 10th European Conf. on Power Electronics and Applications (EPE2003), CD ROM, 2003

[5] M. Y. Ayad, S. Rael, and B. Davat. Hybrid power source using supercapacitors and batteries, Proc. 10th European Conf. on Power Electronics and Applications (EPE2003), CD ROM, 2003.

[6] X. Yan, D. Patterson, Novel Power management for high performance and cost reduction in an electric vehicle, Renewable Energy, vol. 22, pp. 177-183, 2001.

[7] B.P. Taylor, A.J. Brown, D.A. Stone and N. Schofield.: A high power dc-dc converter, employing synchronous rectification of parallel MOSFETs, for use as an electric vehicle battery-tosupercapacitor interface, 10th European Conference on Power Electronics and Applications (EPE2003), 2003, Paper 908, pp. 110, ISBN: 90-75815-07-7.

[8] R. J. Brodd, and K. V. Kordesch. Lead-acid batteries , Book, Wiley-Interscience Publication, ISBN 0-471-08455-7.

[9] P. H. Mellor, N. Schofield, A. J. Brown, and D. Howe. Assessment of supercapacitor/flywheel and battery EV traction systems , Proc. 33rd Int. Symp. on Automotive Technology and Automation (ISATA), Paper 00ELE044, pp.235-242, 2000.

[10] MAXWELL Technologies, Ultracapacitor datasheet, http://www.maxwell.com/datasheets.html.

[11] A. Burke, Ultracapacitors: why, how and where is the technology , Journal of Power Sources, vol. 91, pp. 37-50, 2000.

[12] A. J. Appleby, and F. R. Foulkes. Fuel Cell Handbook , Book, Van Nostrand Reinhold, 1989.

[13] EG\&G Technical Services Inc. Fuel Cell Handbook (Sixth Edition) , Book, U.S. Department of Energy, 2002

[14] MES-DEA, Fuel cell technical datasheet, http://www.cebi.de.

[15] G. Bayer and R. Kr ger.: Development of a hydrogen storage system based on automotive requirements , The 21st Worldwide Battery, Hybrid and Fuel Cell Electric Vehicle Symposium and Exhibition (EVS21), CD-ROM, Paper 197, pp. 1-8, Apr. 2005.

\section{APPENDIX I: ENERGY SOURCE COMPONENT SPECIFICATIONS}

Sealed lead-acid battery data

\begin{tabular}{|l|l|}
\hline Model & HAWKER Genesis EP Series \\
\hline Cell number & 6 cells per module \\
\hline Nominal voltage & $12 \mathrm{~V}(2 \mathrm{~V}$ per cell) \\
\hline Max. voltage & $13.5 \mathrm{~V}$ open circuit $(2.25 \mathrm{~V}$ per cell) \\
\hline Max. charging voltage & $16 \mathrm{~V}(2.67 \mathrm{~V}$ per cell) \\
\hline Min. voltage & $10.2 \mathrm{~V}$ (recommended, $1.7 \mathrm{~V}$ per cell $)$ \\
\hline Max. current & $450 \mathrm{~A}$ \\
\hline Rated energy & 0.1318 to $0.846 \mathrm{kWh}$ \\
\hline Rated capacity & $70 \mathrm{Ah}$ \\
\hline Rated temperature & $20 \mathrm{C}$ \\
\hline Mass & $24.2 \mathrm{~kg}$ \\
\hline Volume & 9.791 \\
\hline Dimension & $331 \mathrm{~mm} \times 168 \mathrm{~mm} \times 176 \mathrm{~mm}$ \\
\hline
\end{tabular}

Supercapacitor data

\begin{tabular}{|l|l|}
\hline Model & MAXWELL PC2500 \\
\hline Nominal voltage & $2.5 \mathrm{~V}$ \\
\hline Max. voltage & $2.7 \mathrm{~V}$ \\
\hline Rated current & $100 \mathrm{~A}$ \\
\hline Rated energy & $7.8 \mathrm{~kJ}$ \\
\hline Rated capacitance & $2500 \mathrm{~F}$ \\
\hline Mass & $0.725 \mathrm{~kg}$ \\
\hline Volume & 0.6091 \\
\hline Dimension & $161 \times 61.5 \times 61.5 \mathrm{~mm}$ \\
\hline
\end{tabular}

MES-DEA 3.0kW prototype fuel cell system [14]

\begin{tabular}{|l|c|}
\hline \multicolumn{2}{|c|}{ (i) Performance data } \\
\hline Unreg. dc output voltage range & $72-114 \mathrm{~V}$ \\
\hline $\mathrm{H}_{2}$ consumption at full-load & $391 \mathrm{n} / \mathrm{min} .(0.2 \mathrm{~kg} / \mathrm{h})$ \\
\hline Max. power output & $3 \mathrm{~kW}$ \\
\hline Open circuit voltage per cell & $0.95 \mathrm{~V}$ \\
\hline Number of cells per system & 120 \\
\hline Active cell area & $61 \mathrm{~cm}^{2}$ \\
\hline \multicolumn{2}{|c|}{ (ii) Operating conditions } \\
\hline Stack temperature & Max. $63^{\circ} \mathrm{C}$ \\
\hline Hydrogen pressure & $0.4-0.7$ bar $($ gauge $)$ \\
\hline Air pressure & Ambient \\
\hline Fuel supply & Pure hydrogen, dead-end mode \\
\hline Ambient temperature & $0{ }^{\circ} \mathrm{C}$ to $+35^{\circ} \mathrm{C}$ \\
\hline Gas humidification & None \\
\hline Working cycle & Continuous \\
\hline Cooling & Force air cooled \\
\hline Stack volume & $410 \times 305 \times 235 \mathrm{~mm}$ \\
\hline Control unit volume & $295 \times 155 \times 95 \mathrm{~mm}$ \\
\hline Stack weight & $9 \mathrm{~kg}$ \\
\hline System weight & $11 \mathrm{~kg}$ \\
\hline \multicolumn{2}{|c|}{ (iii) Vehicle on-board Hydrogen storage } \\
\hline Gas storage & Compressed $\mathrm{H}_{2}$ at $230 \mathrm{bar}$ \\
\hline Storage medium & $3 \times$ carbon composite cylinders \\
\hline Hydrogen mass per cylinder & $0.5 \mathrm{~kg}$ \\
\hline Rated energy per cylinder & $17.5 \mathrm{kWh}$ \\
\hline Cylinder weight & $22 \mathrm{~kg}$ \\
\hline Cylinder dimension & 571 litres \\
\hline Cylinder volume & 901 litres \\
\hline Cylinder gas volume & $236 \times 236 \times 1025 \mathrm{~mm}$ \\
\hline Total storage capability & \\
\hline & \\
\hline
\end{tabular}

\section{APPENDIX II: FUEL CELL MODEL}

The MES-DEA $\mathrm{H}_{2}$ PEM fuel cell voltage vs. cell current density characteristic of Fig. 6 is modelled by an appropriate curve fit, yielding:

$$
\begin{aligned}
V_{\text {cell }}= & k_{a}+k_{b} J+k_{c} J^{2}+k_{d} J^{3}+k_{e} J^{4}+ \\
& k_{f} J^{5}+k_{g} J^{6}+k_{h} J^{7}+k_{i} J^{8}+k_{j} J^{9}+k_{k} J^{10}
\end{aligned}
$$

where $V_{\text {cell }}$ is the fuel cell terminal voltage per cell, $J$ the cell current density. Similarly, the fuel cell stack hydrogen-to-electrical energy efficiency with output load, Fig. 7, is also modelled via a suitable curve fit, viz.:

$$
\eta=a_{a}+a_{b} P_{\%}^{0.5}+a_{c} P_{\sigma_{\%}}+a_{d} P_{\%}{ }^{1.5}+a_{e} P_{\%^{2}}{ }^{2}+a_{f} P_{\%}{ }^{2.5}
$$

where $\eta$ is the fuel cell efficiency, $P_{\%}$ the fuel cell per unit load power. The model curve fit coefficients are given below.

Fuel Cell Model Parameters:

\begin{tabular}{|c|c|}
\hline \multicolumn{2}{|c|}{ Parameters for equation (1): } \\
\hline$k_{a}$ & 0.950602847 \\
\hline$k_{b}$ & -2.111185823 \\
\hline$k_{c}$ & 18.4080918 \\
\hline$k_{d}$ & -101.455289 \\
\hline$k_{e}$ & 333.775762 \\
\hline$k_{f}$ & -684.4227687 \\
\hline$k_{g}$ & 892.8408354 \\
\hline$k_{h}$ & -737.7160864 \\
\hline$k_{i}$ & 371.7575573 \\
\hline$k_{j}$ & -103.5699007 \\
\hline$k_{k}$ & 12.12124403 \\
\hline
\end{tabular}

